\title{
ENHANCING CLEAR EXPRESSION OF RESEARCH QUESTIONS, HYPOTHESES, AND OBJECTIVES THROUGH EFFECTIVE USE OF SCIENTIFIC ENGLISH
}

\author{
Received: Oct 28, 2019 \\ Accepted: Oct 30, 2019
}

Edward Barroga ${ }^{1^{*}}$ https://orcid.org/0000-0002-8920-2607

1St. Luke's International University, Tokyo, Japan

\section{*Corresponding author:}

Edward Barroga, St. Luke's International University, Tokyo, Japan;

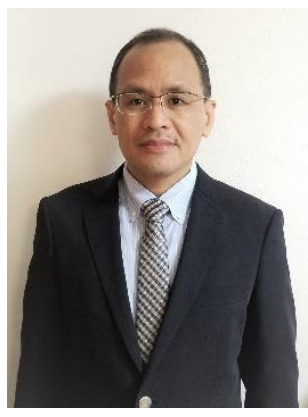

Twitter handle: @BarrogaEdward; E-mail: edward-barroga@slcn.ac.jp

Keywords: Writing, English, Healthcare, Education, Japan, Central Asia

How to cite: Barroga E. Enhancing clear expression of research questions, hypotheses, and objectives through effective use of scientific English. Cent Asian J Med Hypotheses Ethics 2020;1(1): 63-65.

https://doi.org/10.47316/caimhe.2020.1.1.09

Many healthcare professionals, particularly nonAnglophone authors, continue struggling to properly write and publish their articles in high-rank peerreviewed journals. This overwhelming writing task is confounded by inability to formulate their research question, hypothesis, and objective in understandable scientific English. The resultant challenges lead to inappropriate choice of study design, disorganized research, unprofessional data reporting and interpretation, and weak conclusions.

The inability of Japanese medical students to write, edit, and discuss English journal articles is assessed in a recent study that points to the reliance on observation rather than participation, poor critical thinking skills, lack of emphasis on scientific inquiry and research writing, inadequate use of English for studies, and nonmedical background of English instructors [1]. Advanced teaching techniques, more emphasis on critical thinking, regular processing of research items, and motivation to publish great articles are believed to overcome the problems [1].

St. Luke's International University in Tokyo is one of the few universities in the Asia Pacific region that has developed an academic writing help desk and journal article writing courses to support its students and faculty [2]. The support is particularly aimed to motivate master and doctorate candidates advance their English writing skills and increase the number of articles in international journals. These programs are updated regularly to meet the ever-increasing requirements of the publishing enterprise. 


\section{Central Asian Journal of Medical Hypotheses and Ethics| \\ 2020; Vol 1}

In Central Asian countries, no such scientific English courses exist. The Central Asian Journal of Medical Hypotheses and Ethics (CAJMHE) may fill the gap by publishing methodology articles presenting globally acceptable writing standards, structure of hypotheses, and ethics requirements. Using this journal for establishing cooperation between Central Asian and Asia Pacific researchers, educators, and editors is supposedly the optimal way forward.

The CAJMHE is an online-only platinum openaccess peer-reviewed journal focusing on medicine and health policy. It welcomes innovative ideas, hypotheses, and recommendations to solve the regional problems of research and publication ethics. It is aimed to regularly publish didactic articles for enhancing the readers' knowledge of hypotheses, ethics, and communication terminology.

Welcoming the launch of yet another promising periodical, it is hoped that its editors will make an effort to publish more materials that instruct how to formulate research questions. This is the initial step of research that explores a specific issue and highlights knowledge gaps. Clearly defined research questions may help choose the most appropriate study design, enroll relevant subjects, collect reliable data, and end up with evidencebased analysis [3]. There are some widely publicized recommendations and research tools that can be employed by the CAJMHE editors to instruct their authors and increase the quality of the published articles. The best examples of research reporting standards are available from the EQUATOR Network website (http://www.equatornetwork.org/).

The CAJMHE is supposed to discuss issues of working hypotheses of original research studies and scientific hypotheses. For both types of hypotheses, comprehensive literature searches are advisable to clearly formulate objectives and plan well-structured and evidence-based analyses. Properly formulated objectives positively influence later stages of research and writing.

It is assumed that the journal primarily serves the interests of non-Anglophone authors who are encouraged to express their ideas and formulate hypotheses in understandable scientific English. There are five linguistic areas that should be mastered by scientific authors to publish readable and influential articles [4]: style (abbreviations, hyphenation, number style, capitalization and italicizing, consistent use of American and British English), format (referencing, graphics, spacing), grammar (tenses, phrasal verbs, articles, prepositions, punctuation), structuring text (correct order of words, sentences, paragraphs, parallelism), logical flow and scientific terminology.

Additionally, there are four areas of competence that are required for writing professionally [4]: content-based writing by referring to specific examples, analytical writing by correctly using professional terms, revising texts, proofreading and polishing texts.

In the process of helping authors, the CAJMHE editors should provide relevant guidance for comprehensively and systematically processing literature, adhering to ethical norms, and proposing truly innovative ideas. Social media channels should be also actively employed for postpublication evaluation and streamlining the flow of articles from Central Asian and other countries.

The editors' sincere efforts to support novice authors, as stated in the journal instructions, is particularly encouraging. Formulating a clear research question, hypothesis, and objective through the effective use of scientific English and skilled processing of literature will allow publishing innovative, readable, and truly influential articles.

\section{FUNDING}

None

\section{AUTHOR CONTRIBUTIONS}

EB contributed substantively to the writing of this manuscript. He takes full responsibility for the integrity of all parts of the manuscript.

\section{CONFLICT OF INTEREST}

None declared

\section{DISCLAIMER}

No part of this manuscript is copied from or published elsewhere. 


\section{REFERENCES}

1. Barroga EF, Mitoma H. Critical thinking and scientific writing skills of non-Anglophone medical students: $A$ model of training course. J Korean Med Sci 2019;34(3):e18.

2. Barroga EF, Inoue M, Fujita H, Sato K, Matsumoto N, Nakajima K, et al. The academic writing desk of St. Luke's International University: Providing increasing mentoring support in the areas of academic research, writing, presentation, and publishing. Bulletin of St. Luke's International University 2017;3:34-40.

3. Farrugia F, Petrisor BA, Farrokhyar F, Bhandari M. Research questions, hypotheses and objectives. Can J Surg 2010;53(4):278-281.

4. Coghill AM, Garson LR, American Chemical Society. The ACS Style Guide: Effective Communication of Scientific Information. 3rd ed. Washington, DC; Oxford; New York: American Chemical Society; Oxford University Press, 2006.

Ғылыми ағылшын тілін тиімді қолдану арқылы зерттеу сұрақтары, гипотезалар мен мақсаттардың нақты көрінісін жетілдіру

Түйін сөздер: Кітаптар жазу, Ағылшын тілі, Денсаулық сақтау, Білім беру, Жапония, Орталық Азия

Дәйексөз үшін: Barroga Е. Ғылыми ағылшын тілін тиімді қолдану арқылы зерттеу сұрақтары, гипотезалар мен мақсаттардың нақты көрінісін жетілдіру. Медициналық гипотеза мен этиканың Орта Азиялық журналы. - 2020. - №1 (1). - Б. 63 - 65. https://doi.org/10.47316/cajmhe.2020.1.1.09

Повышение точности формулировок исследовательских вопросов, гипотез и целей путем эффективного использования научного английского языка

Ключевые слова: Написание книг, Английский язык, Здравоохранение, Образование, Япония, Центральная Азия

Для цитирования: Баррога Е. Повышение точности формулировок исследовательских вопросов, гипотез и целей путем эфффективного использования научного английского языка. Центральноазиатский журнал медицинских гипотез и этики. - 2020. - №1(1). - С. 63 - 65. https://doi.org/10.47316/cajmhe.2020.1.1.09 